\title{
Mineralogical Variations within Two Widespread Holocene Tephra Layers from Cascade Range Volcanoes, U.S.A.
} Variations minéralogiques dans deux vastes couches holocènes de tephra provenant de volcans de la chaîne des Cascades, États-Unis

\author{
Mineralogische Schwankungen in zwei ausgedehnten \\ holozänen Tephra-Schichten von den Vulkanen der \\ Cascade-Kette, U.S.A
}

\author{
Étienne Juvigné et Stephen C. Porter
}

Volume 39, numéro 1, 1985

URI : https://id.erudit.org/iderudit/032580ar

DOI : https://doi.org/10.7202/032580ar

\section{Aller au sommaire du numéro}

\section{Éditeur(s)}

Les Presses de l'Université de Montréal

\section{ISSN}

0705-7199 (imprimé)

1492-143X (numérique)

\section{Découvrir la revue}

\section{Citer cet article}

Juvigné, É. \& Porter, S. C. (1985). Mineralogical Variations within Two Widespread Holocene Tephra Layers from Cascade Range Volcanoes, U.S.A. Géographie physique et Quaternaire, 39(1), 7-12.

https://doi.org/10.7202/032580ar

\section{Résumé de l'article}

Le contenu en minéraux denses a été étudié dans des échantillons provenant de deux retombées volcaniques largement répandues sur le nord-ouest des États-Unis et sur le sud-ouest du Canada. L'une d'entre elles correspond à l'explosion du mont Mazama (Oregon) survenue il y a environ 6700 ans; elle est connue sous le nom de " couche $\mathrm{O}$ ». L'autre résulte d'une explosion du mont St. Helens qui a eu lieu il y a environ 3400 ans; elle est connue sous le nom de " couche Yn ». Dans chacun des deux lobes, le contenu en minéraux denses diminue avec la distance aux volcans respectifs, et des variations spatiales systématiques de l'association de minéraux denses transparents dans le lobe de la " couche 0 » ont été mises en évidence. Ces variations sont comparées à celles qui ont été observées dans les retombées récentes des volcans mont St. Helens (É.-U., 18 mai 1980) et El Chichôn (Mexique, mars-avril 1982). Elles sont expliquées par des processus de sélection qui ont lieu dans les nuages de poussières au cours du transport dans l'atmosphère. 


\section{MINERALOGICAL VARIATIONS WITHIN TWO WIDESPREAD HOLOCENE TEPHRA LAYERS FROM CASCADE RANGE VOLCANOES, U.S.A.}

Étienne JUVIGNÉ and Stephen C. PORTER, Laboratoire de géomorphologie et de géologie du Quaternaire, Université de Liège, B-4000 Liège, Belgique, and Quarternary Research Center, University of Washington, Seattle, Washington 98195, U.S.A.

\begin{abstract}
The heavy mineral content of volcanic ash from Mount Mazama (layer O) and Mount St. Helens (layer Yn) decreases downwind from each volcano. The transparent heavy mineral suite of layer $\mathrm{O}$ also varies downwind because of differences in specific gravity and shape of the grains, reflecting sorting processes during transportation in the atmosphere. In the first few tens of kilometers from the volcano some values strongly deviate from the general trend. This is attributed to exceptional turbulence at the time of eruptions in the vicinity of the vent.
\end{abstract}

RÉSUMÉ Variations minéralogiques dans deux vastes couches holocènes de tephra provenant de volcans de la chaine des Cascades, États-Unis. Le contenu en minéraux denses a été étudié dans des échantillons provenant de deux retombées volcaniques largement répandues sur le nordouest des États-Unis et sur le sud-ouest du Canada. L'une d'entre elles correspond à l'explosion du mont Mazama (Oregon) survenue il y a environ 6700 ans; elle est connue sous le nom de "couche $\mathrm{O}$ ". L'autre résulte d'une explosion du mont St. Helens qui a eu lieu il y a environ 3400 ans; elle est connue sous le nom de "couche $Y n$ ". Dans chacun des deux lobes, le contenu en minéraux denses diminue avec la distance aux volcans respectifs, et des variations spatiales systématiques de l'association de minéraux denses transparents dans le lobe de la "couche $\mathrm{O}$ " ont été mises en évidence. Ces variations sont comparées à celles qui ont été observées dans les retombées récentes des volcans mont St. Helens (É.-U., 18 mai 1980 ) et El Chichón (Mexique, mars-avril 1982). Elles sont expliquées par des processus de sélection qui ont lieu dans les nuages de poussières au cours du transport dans l'atmosphère.
ZUSAMMENFASSUNG Mineralogische Schwankungen in zwei ausgedehnten holozänen Tephra-Schichten von den Vulkanen der Cascade-Kette, U.S.A., In Proben, die aus zwei ausgedehnten vulkanischen Niederschlägen im Nord-Westen der U.S.A. und dem Süd-Westen Kanadas stammen, wurde der Gehalt an dichten Mineralen studiert. Der eine Niederschlag entspricht dem Ausbruch des Mount Mazama (Oregon), der vor etwa 6700 Jahren stattgefunden hat; er ist unter der Bezeichnung "Schicht O" bekannt. Der andere entstammt einem Ausbruch des Mount St. Helens, der vor ungefähr 3400 Jahren stattgefunden hat; er ist unter der Bezeichnung "Schicht Yn" bekannt. In jedem der zwei Ausschnitte nimmt der Gehalt an dichten Mineralen ab, entsprechend zur Entfernung zum jeweiligen Vulkan, und im Ausschnitt der "Schicht O" konnten systematische örtliche Schwankungen in der Assoziation der transparenten dichten Minerale nachgewiesen werden. Diese Schwankungen werden verglichen mit denen, die in den neueren Niederschlägen der Vulkane von Mount St. Helens (U.S.A., 18. Mai 1980) und El Chichón (Mexiko, März-April 1982) beobachtet wurden. Sie werden erklärt durch Selektionsprozesse, die in den Staubwolken während des Transports in der Atmosphäre stattgefunden haben. 


\section{INTRODUCTION}

Quaternary tephra layers have proved useful in correlating and dating various surficial deposits in northwestern United States (e.g., MULLINEAUX, 1974; PORTER, 1981). Although heavy minerals of the most important tephra units have been described and have been used to help differentiate the various layers, reported data are largely semi-quantitative (CRANDELL et al., 1962; RANDLE et al. 1971; MULLINEAUX, 1974; MULLINEAUX, et al., 1975). During the past century variations within tephra lobes have been observed on the basis of component or bulk chemical analyses (o.g., FISHER and SCHMINKE, 1984, p. 155-162). In the last 20 years, correlations based on chemical analyses were preferred over those based on mineral suites. This tendency was partly due to the realization that although variations within mineral suites of a tephra lobe may be known, the functions controlling those variations were not known. Such functions could only be determined from observed eruptions, for it may not be possible always to be certain that scattered occurrences of ash represent the same tephra fall.

To evaluate the possibility of correlating tephra using mineral suites, JUVIGNE (1983b) investigated the tephra of the MarchApril, 1982 eruptions of El Chichón volcano of Mexico and developed a theoretical model for nine groups of minerals. This study provided an incentive to investigate older tephra units in the Pacific Northwest to see if similar variations could be observed. The units investigated were layer $\mathrm{Yn}$, erupted from Mount St. Helens, Washington, about $3400 \mathrm{yr}$ BP, and layer $\mathrm{O}$, which resulted from a major eruption of Mount Mazama, Oregon, about $6700 \mathrm{yr}$ BP. The latter was of particular interest because KITTLEMAN (1973, p. 2957) concluded that "within about $300 \mathrm{~km}$ of Crater Lake ... the proportion of heavy minerals does not change with increasing distance".

\section{METHODS}

Samples collected specifically for this study and others obtained from collections in the University of Washington were treated by the following method:

1. A sample was sieved with water through screens of 500 microns and 63 microns, without physical pressure being applied to the sample.

2. The 63-500 microns fraction was dried in an oven.

3. A $500 \mathrm{mg}$ split was taken from each sample.

4. The split was shaken in $10 \mathrm{ml}$ of purified bromoform and centrifuged to separate the heavy mineral fraction.

5. By repetitive centrifuging and basal freezing of the concentrate with liquid nitrogen, the heavy minerals were concentrated.

6. After drying and weighing the sample to the nearest $10{ }^{5} \mathrm{gm}$, heavy mineral grains were mounted on a slide in Canada balsam and 200 grains were counted using the ribbon method (VAN HARTEN, 1965).

\section{NOMENCLATURE OF TRANSPARENT HEAVY MINERALS}

Orthopyroxenes, amphiboles, and clinopyroxenes are the most common transparent heavy minerals found in the samples. Most are covered by vesicular glassy coatings.
Most orthopyroxenes are elongate prisms which, when mounted on a slide, show only sections parallel to the main axis. On these sections there appears a marked green to pinkish-brown pleochroism. Such orthopyroxenes were identified as hypersthene.

Traces of clinopyroxenes were found in most samples, with large quantities being locally present in layer $\mathrm{O}$ (Mount Mazama). They occur as elongated prisms; the typical bright green color of these grains suggests that they are augite.

Amphiboles are often elongated prisms that display only sections parallel to the main axis. They have been divided into four groups based on color differences:

- Yellow or light brown to dark brown (basaltic hornblende);

- brownish green to dark green (brown hornblende);

— light green to dark green (green hornblende);

- almost colorless (cummingtonite).

\section{STATISTICAL ANALYSES}

Because of an insufficient number of samples (20 for layer $\mathrm{O}$ and 8 for layer $\mathrm{Yn}$ ), trend surfaces of variations of the percentages cannot provide isoline maps similar to those computed for the 1982 eruption of El Chichón (DONNAY and JUVIGNÉ, 1985). However, comparison is possible with the model established by JUVIGNÉ (1983) to characterize variations along the main axis of a lobe.

For this purpose regression analyses of each set of values were carried out, with parameters plotted as a function of the distance from the volcano. This method does not take into account lateral variations in the lobe, as demonstrated by JUVIGNÉ and SHIPLEY (1983), JUVIGNÉ (1983), and DONNAY and JUVIGNE (1985). Furthermore, the position of each sample within its bed it not available. Therefore variations resulting from differences in settling velocity cannot be taken into account. As a consequence, one can expect larger deviations of individual values from the theoretical curves and a decrease of the coefficient of determination $\left(r^{2}\right)$ (Figs. 2 and 3).

\section{RESULTS}

Layer O (Mount Mazama)

The Mazama tephra was produced by a massive Holocene eruption that distributed ash widely throughout an area of at least $900,000 \mathrm{~km}^{2}$ (FRYXELL, 1965) (Fig. 1a). Samples of the ash were obtained from sites in Oregon northeast of the source, in Washington at a number of localities lying between Puget Sound and the Idaho border, and in southwestern Canada (Fig. 1b).

The most abundant minerals are orthopyroxene (hypersthene), amphibole (basaltic hornblende), and clinopyroxene (augite) which together comprise at least 92.5 percent of all transparent heavy minerals in each sample (Table I). The remaining fraction includes traces of apatite and zircon, as well as unidentified trace minerals.

The regression analyses of each set of values show the following systematic variations as a function of the distance from the volcano: 

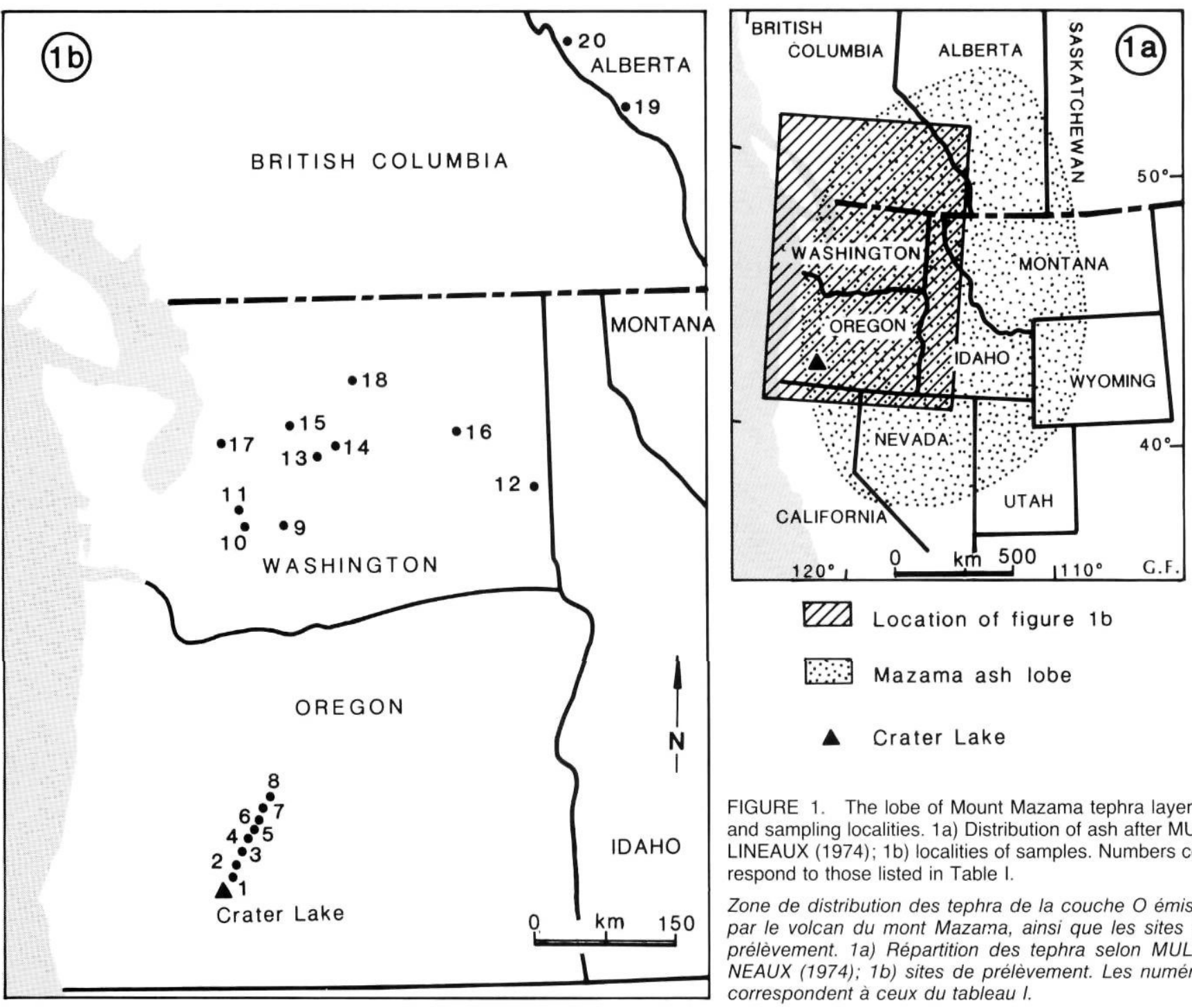

FIGURE 1. The lobe of Mount Mazama tephra layer O and sampling localities. 1a) Distribution of ash after MULLINEAUX (1974); 1b) localities of samples. Numbers correspond to those listed in Table I.

Zone de distribution des tephra de la couche $O$ émises par le volcan du mont Mazama, ainsi que les sites de prélèvement. 1a) Répartition des tephra selon MULLINEAUX (1974); 1b) sites de prélèvement. Les numéros correspondent à ceux du tableau I.

1. a decrease of heavy mineral content (Fig. 2, curve $Y_{1}$ );

2. a decrease in the percentages of both clinopyroxenes (Fig. 2, curve $\mathrm{Y}_{3}$ ) and orthopyproxenes (Fig. 2, curve $\mathrm{Y}_{4}$ ); 3. an increase in the percentages of amphiboles (Fig. 2, curve $Y_{2}$ ).

In order to compare the results with the model established by JUVIGNÉ (1983), the orthopyroxene/amphibole ratio and clinopyroxene/amphibole ratio were calculated (Table I). Regression analyses of each set of values provide the following functions:

Orthopyroxene/amphibole: $Y_{5}=6.9 \mathrm{e}^{0.01 x}\left(r^{2}=0.55\right)$,

Clinopyroxene/amphibole: $Y_{6}=0.83$ e $0.01 \times\left(r^{2}=0.40\right)$.

Both ratios decrease with distance from the volcano. Furthermore they have the same regression coefficient $(-0.01)$, which implies that the ratio of orthopyroxene to clinopyroxene does not vary in the lobe.

All the preceding results are consistent with those obtained in studies of the May 19, 1980 eruption of Mount St. Helens (JUVIGNÉ and SHIPLEY, 1983) and of El Chichón MarchApril 1982 eruptions (JUVIGNÉ, 1983).
In the first few tens of kilometers from the volcano some values strongly deviate from the general trend. This was also observed in the El Chichón ash-fall deposits and was explained as resulting from exceptional turbulence in the vicinity of the vent (DONNAY and JUVIGNÉ, 1985).

Our results differ from those of KITTLEMAN (1973) who, contrary to expectations, found that in the Mazama ash layer "total abundance of free crystals appears to increase with increasing distance" from Crater Lake "and the proportion of heavy minerals does not change..." (p. 2963). The apparent discrepancy may be a result of different methods used in each study. We established the heavy mineral content by separating the 63-500 micron fraction in purified bromoform using a centrifuge and then weighed both the light and heavy fraction. Kittleman separated the glass fraction from both the light and heavy crystals by settling and flotation in a solution of bromoform and ethanol (specific gravity $=2.4$ ) using the funnel method. Then the crystals were identified and counted.

The efficiency of the funnel method and the centrifuge methods have been compared by different workers. For ex- 


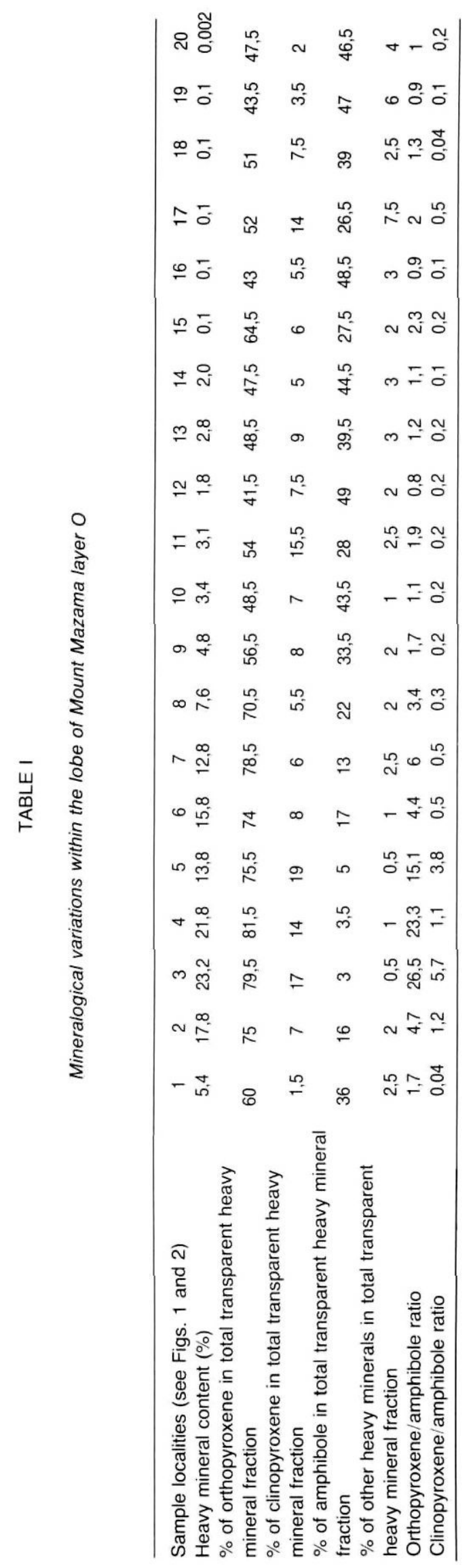

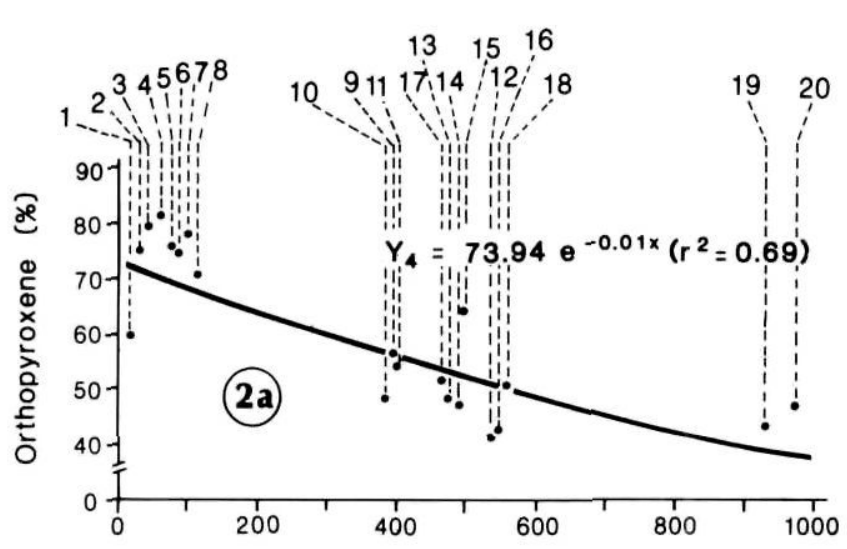
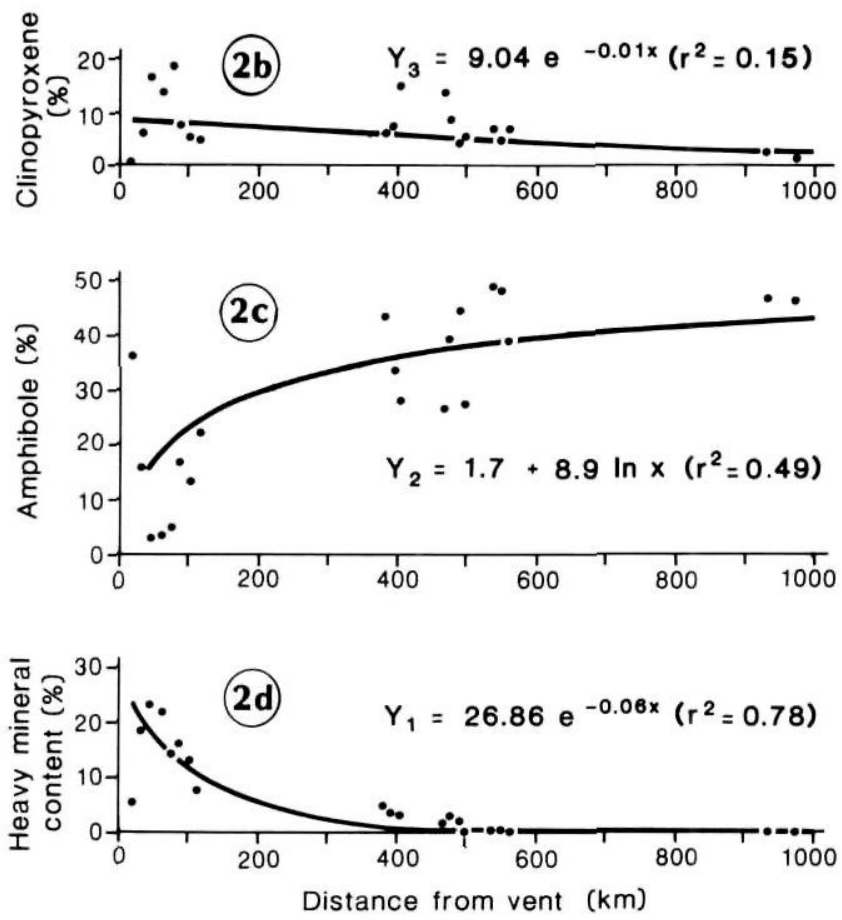

FIGURE 2. Regression data for mineralogical variations within the lobe of Mount Mazama tephra layer O. See Figure 1 for sample localities.

Analyses de régression des parts de chacun des minéraux dans le lobe de la couche $O$ du mont Mazama. Voir la figure 1 pour la localisation des sites.

ample, JUVIGNE (1979) showed that in using the funnel method, the efficiency of the technique decreased below the 300-micron size.

Similarly, different results in the study of the transparent mineral suites may be due to the fact that Kittleman took into account both light and heavy, and opaque and transparent crystals. Using this approach, the proportion of each heavy mineral is very low and the standard deviations are relatively high. This may explain why almost all the values overlap. On the other hand, our approach, which involved counting only heavy minerals, results in relatively low standard deviations and the values overlap less frequently. 
Differences in mineral content of volcanic ash resulting from methodological factors have previously been pointed out (e.g., JUVIGNÉ, 1983).

Layer Yn (Mount St. Helens)

Eight samples of layer $\mathrm{Yn}$, from sites as far as $800 \mathrm{~km}$ from the volcano, were analyzed (Fig. 3a; Table II). The overall trend is a decrease of the heavy mineral content with distance from the volcano (Fig. 3b, curve $Y_{7}$ ), but in the first few tens of kilometers from the volcano some values deviate strongly from the general trend.

The most abundant minerals are amphiboles (93 to 95 percent). Brown hornblende, green hornblende, and cummingtonite are present. Orthopyroxene (hypersthene) reaches a maximum of about 5 percent. The remaining minerals include traces of apatite, zircon, and clinopyroxene (augite), as well as unidentified minerals.

Regression analyses of the orthopyroxene/amphibole ratio gives a function, $Y_{8}$, which indicates that there is no variation with distance from the volcano. Such an unexpected result might be explained by the very low percentages of orthopyroxene (1.5 to 4.5 percent). Such values will have standard deviations of about 2 percent when 200 grains are counted. At this level the ratios are considered unreliable. This conclusion is consistent with our opinion regarding the comparative results of Kittleman's work on the Mazama tephra and our own.

FIGURE 3. Regression data for mineralogical variations within the lobe of tephra layer Yn from Mount St. Helens. 3a) Distribution of tephra after MULLINEAUX (1974). Numbers correspond to sampling localities listed in Table II; 3b) heavy mineral content; 3c) orthopyroxene/ amphibole ratio.

Analyse de régression des parts de chacun des minéraux dans le lobe des tephra de la couche Yn émise par le mont St. Helens. 3a) Répartition des tephra selon MULLINEAUX (1974). Les numéros correspondent aux sites de prélèvement du tableau II; $3 b$ ) contenu en minéraux denses; $3 c$ ) rapport orthopyroxène/amphibole.
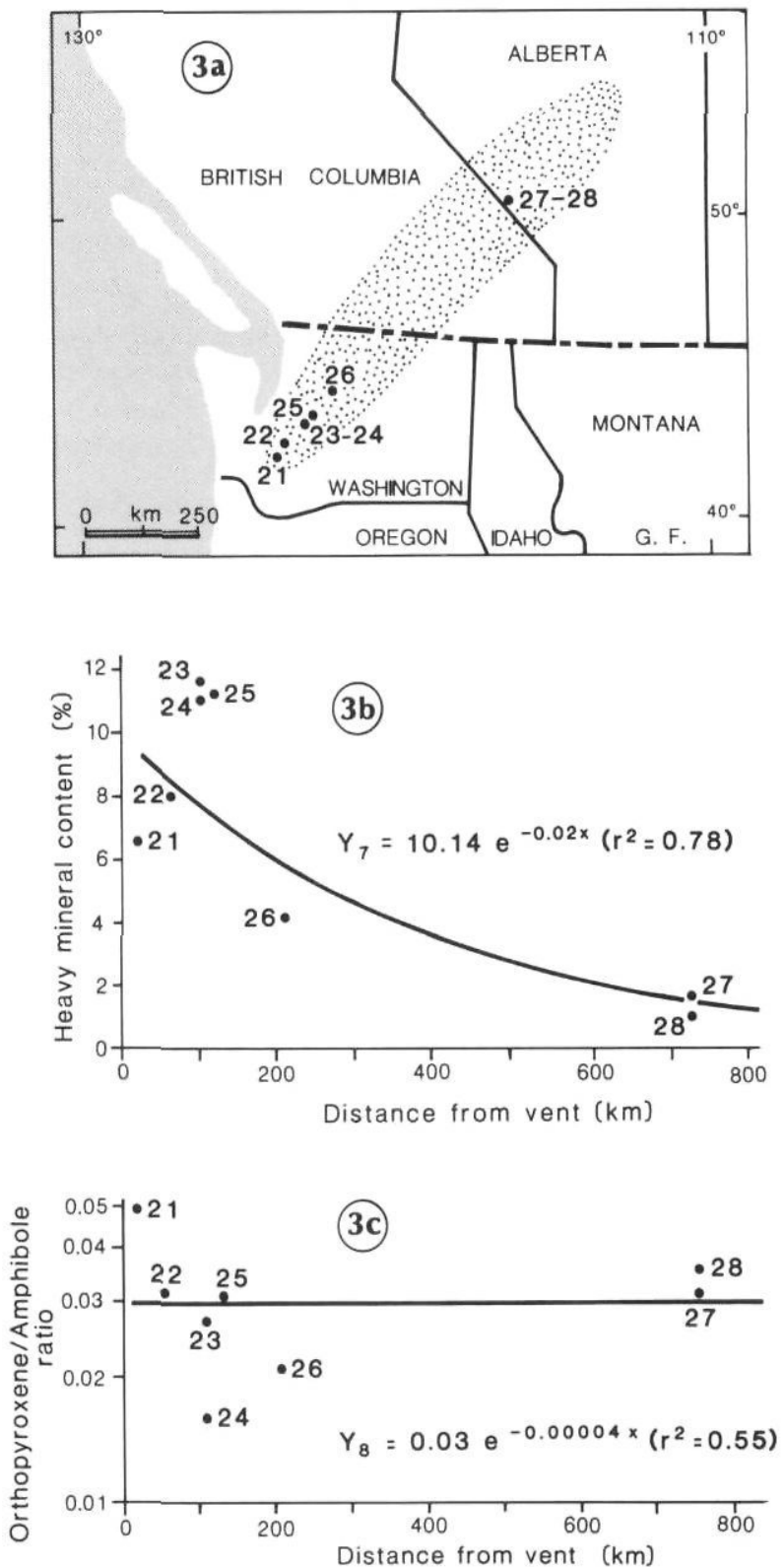

TABLE ॥

Mineralogical variations within the lobe of Mount St. Helens layer Yn

\begin{tabular}{|c|c|c|c|c|c|c|c|c|}
\hline Sample localities (see Fig. 3) & 21 & 22 & 23 & 24 & 25 & 26 & 27 & 28 \\
\hline $\begin{array}{l}\text { Heavy mineral content (\%) } \\
\% \text { of amphibole (hornblende) } \\
\text { in total transparent heavy }\end{array}$ & 6,4 & 7,9 & 11,5 & 11,8 & 11,6 & 4,2 & 1,0 & 1,7 \\
\hline $\begin{array}{l}\text { mineral fraction } \\
\% \text { of orthopyroxene } \\
\text { (hypersthene) in total } \\
\text { transparent heavy mineral }\end{array}$ & 93,0 & 95,0 & 96,5 & 93,0 & 96,5 & 95,0 & 96,0 & 96,0 \\
\hline $\begin{array}{l}\text { fraction } \\
\% \text { of other heavy minerals in } \\
\text { total transparent heavy }\end{array}$ & 4,5 & 3,0 & 2,0 & 1,5 & 3,0 & 2,0 & 3,0 & 3,5 \\
\hline $\begin{array}{l}\text { mineral fraction } \\
\text { Orthopyroxene/amphibole }\end{array}$ & 2,5 & 2,0 & 1,5 & 5,5 & 0,5 & 3 & 1 & 0,5 \\
\hline ratio & 0,04838 & 0,03157 & 0,02727 & 0,01612 & 0,03108 & 0,02105 & 0,03125 & 0,03645 \\
\hline
\end{tabular}




\section{CONCLUSIONS}

Plotted mineralogical variations within the lobe of the widespread tephra layer O (Mount Mazama) show that both the amount of the heavy mineral fraction and the ratio of orthopyroxene and/or clinopyroxene to amphibole decrease downwind from the volcano, a result which differs from that obtained earlier by KITTLEMAN (1973).

In the lobe of Mount St. Helens layer Yn a similar downwind decrease of the heavy mineral fraction has been demonstrated, but due to very low percentages of orthopyroxene, the orthopyroxene/amphibole ratios are considered unreliable.

The overall trends can be explained by sorting during transport in the atmosphere, and result from differences in both specific gravity and shape of the grains. They are consistent with the theoretical model proposed by JUVIGNE (1983) based on the March-April 1982 tephra erupted by El Chichón volcano.

Strong deviation of some values from the general trend within a few tens of kilometers of the volcano is explained as resulting from exceptional turbulence in the plume immediately downwind from the vent.

The use of functions ruling the variations of minerals within tephra layers reemphasizes the potential for correlating volcanic ash units at great distances from their sources through the use of mineral suites.

\section{ACKNOWLEDGMENTS}

This research was conducted at the Quaternary Research Center, University of Washington and was supported by a NATO grant to Juvigné. We thank R. H. King (University of Western Ontario, Canada) for providing samples from layers $\mathrm{O}$ and $\mathrm{Yn}$ collected in southwestern Canada. We also thank the reviewers, Robert J. Fulton and John A. Westgate, for their useful comments.

\section{REFERENCES}

CRANDELL, D. R., MULLINEAUX, D. R., MILLER R. D. and RUBIN, M. (1962): Pyroclastic deposits of recent age at Mount Rainier, Washington, U.S. Geological Survey Professional Paper, 450-D, p. 64-65.
DONNAY, J. P. and JUVIGNÉ, É. (1985): Analyse de variations minéralogiques par surfaces de tendance dans les tephra du volcan El Chichón (Chiapas, Mexique), Eiszeitalter und Gegenwart, in press.

FISHER, R.V. and SCHMINKE, H.-U. (1984): Pyroclastic Rocks, Springer-Verlag, Berlin-Heidelberg-New York-Tokyo, $472 \mathrm{p}$.

FRYXELL, R. (1965) : Mazama and Glacier Peak volcanic ash layers: relative ages, Science, 147, p. 1288-1290.

GALEHOUSE, J. S. (1969): Counting grain mounts: number percentage vs. number frequencies, Journal of Sedimentary Petrology, 39 , p. $812-815$.

JUVIGNE, É. (1979): Scheidetrichtermetode oder Zentrifugaltrennung zur quantitativen Gewinnung von Schwermineralen, Senckenbergiana Maritima, 11, p. 171-174.

(1983): Les variations minéralogiques dans les retombées de 1982 du volcan El Chichón (Chiapas, Mexique) et leur intérêt pour la téphrostatigraphie, Annales de la Société géologique de Belgique, 106, p. 311-325.

JUVIGNÉ, É. and SHIPLEY, S. (1983) : Distribution of heavy minerals in the downwind lobe of the May 18 eruption of Mount St. Helens, Eiszeitalter und Gegenwart, 33, p. 1-7.

KITTLEMAN, L. R. (1973): Mineralogy, correlation, and grain-size distribution of Mazama tephra and other postglacial pyroclastic layers, Pacific Northwest, Geological Society of America Bulletin, 84, p. 2957-2980.

MULLINEAUX, D. R. (1974): Pumice and other pyroclastic deposits in Mount Rainier National Park, Washington, U.S. Geological Survey Bulletin, 1326, $83 \mathrm{p}$.

MULLINEAUX, D. R., HYDE, J. H. and RUBIN, M. (1975): Widespread late-glacial and postglacial tephra deposits from Mount St. Helens volcano, Washington, Journal of Research of the U.S. Geological Survey, 3, p. 329-335

PORTER, S. C. (1981): Use of tephrochronology in the Quaternary geology of the United States, in S. Self and R. S. J. Sparks, ed., Tephra Studies, D. Reidel, p. 135-160.

RANDLE, K., GOLES, G. G. and KITTLEMAN, L. R. (1971): Geochemical and petrographical characterisation of ash samples from Cascade Range volcanoes, Quaternary Research, 1, p. 261-282.

VAN HARTEN, D. (1965): On the estimation of relative grain frequencies in heavy mineral slides, Geologie en Mijnbouw, 44, p. 357-363. 